\title{
OBITUARY
}

\section{SIR \\ Leonard Gregory Parsons}

F.R.S., M.D., F.R.C.P., F.R.C.O.G.

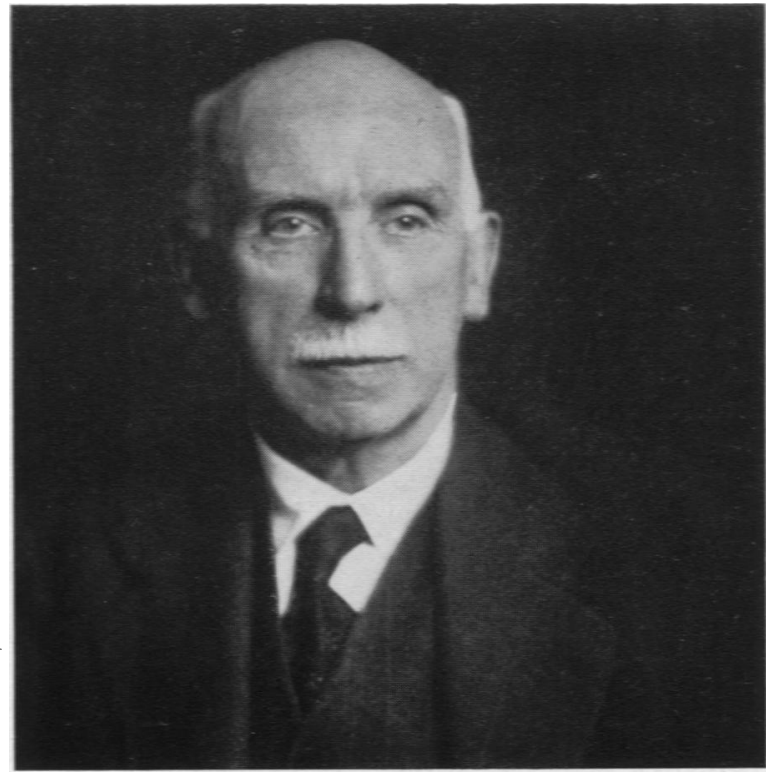

his first important communications was the Arris and Gale Lecture before the Royal College of Surgeons in 1912. The subject of this address was 'The Mechanism and Treatment of Shock' and was based on studies carried out in association with Mr. Tyrrell Gray during the time they had been working together in London. Disorders of growth and nutrition soon attracted his interest and enthusiasm, and his determination to extend knowledge and understanding of this subject remained unabated for the next $\mathbf{4 0}$ years. His paper on 'Infantilism Associated with Chronic Interstitial Nephritis' in 1911 was an early and important contribution to some of the features of renal rickets which was not very widely recognized at that time.

During the 1914-18 war Parsons served overseas with the Royal Army Medical Corps as medical specialist to a military hospital in Serbia and consultant physician to the Serbian Army. For these distinguished services he was awarded the Order of St. Sava.

On demobilization in 1918, he returned with renewed vigour to his work for children. Soon afterwards the Children's Hospital, which had moved to new and larger buildings, was recognized for the training of students and Parsons began to hold regular clinical and tutorial classes, which were largely attended and welcomed by the undergraduates. In 1923, he was elected a Fellow of the Royal College of Physicians and appointed Goulstonian Lecturer: the subject he chose for these lectures was 'Some Wasting Disorders of Infancy.' Further evidence of his research work 
on nutrition was given when he delivered the Ingleby Lectures in Birmingham University in 1928 on 'Recent Advances in our Knowledge of Rickets and Allied Disorders,' and he was one of the first to show that rickets could be cured by giving irradiated cholesterol.

From this time onwards a steady stream of important papers came from his pen. Coeliac disease and the anaemias of infancy were two subjects in particular which he, with his team of associates, subjected to detailed and painstaking investigation. Parsons was one of the first, if not the first, to demonstrate that hydrops foetalis, icterus gravis, and haemolytic disease of the newborn, were merely different clinical manifestations of an underlying haemolytic process of unknown aetiology. This was in 1933, and these investigations and demonstrations paved the way for the work of Levine and others who established the significance of the $R h$ factor six years later. His investigations into fat metabolism and coeliac disease formed the subject of the Ratchford Memorial Lecture in the University of Cincinnati in 1931. Ascorbic acid was first synthesized by Sir Norman Haworth, Professor of Chemistry, University of Birmingham, and in 1933 Parsons demonstrated to the Royal Society of Medicine the first case of scurvy successfully treated with ascorbic acid.

While on a visit to America in 1925 he met Abraham Flexner who had written that modern paediatrics was unknown in Great Britain except in Glasgow. Parsons was determined that he would force Flexner to retract this statement which he was able to do in a comparatively short time. Indeed, the national and international reputation that the Birmingham Medical School now holds in the sphere of paediatrics has been gained by Parsons' leadership, foresight, and wise guidance. The extension to the wards and special departments of the Children's Hospital have been due almost entirely to his initiative and direction. He was Chairman of the Committee of Management of the Hospital in 1939 and much of the work for the planning and designing of the infants' wing devolved on his shoulders. These buildings, the like of which exist nowhere else in this country, were conceived by him in 1929 and completed in 1940. In March, 1947, at a special dedication ceremony, this building was named the 'Leonard Parsons Block' and will thus remain a perpetual memorial to his work on behalf of paediatrics and Birmingham University.

In his endeavours still further to promote the study and recognition of paediatrics and child health, Parsons was actively interested in establishing the Diploma of Child Health of the Royal Colleges in 1935, and he acted as one of the examiners for several years.

During all these years Parsons was steadily establishing an international reputation as a brilliant and outstanding paediatrician, and prizes and awards began to be bestowed upon him in steadily increasing numbers. He was elected VicePresident of the International Paediatric Congress at Stockholm in 1930, delivered the Ratchford Memorial Lecture at the University of Cincinnati in 1931, and the Blackader Memorial Oration before the Canadian Medical Society in 1946. In this country he was President of the Children's Section of the Royal Society of Medicine in 1932, William Withering Lecturer, Birmingham University, in 1937, and Dawson Williams Memorial Lecturer and prize winner in 1938. He was an original member of the British Paediatric Association, and as President from 1942 to 1945 he played an active role in extending its activities and enhancing its prestige. Despite all these multifarious and onerous medical activities and responsibilities, Parsons maintained a freshness and a sense of responsibility for medical education and was taking his full share in the work and activities of Birmingham University. As has already been said, when he joined the staff of the Birmingham Children's Hospital there was no place for the teaching of paediatrics in the curriculum of the medical students. In 1934, clinical clerking in the Children's Hospital was made compulsory for all students in their final year, and in 1943 paediatrics was made a special and distinct part of the final examination, Birmingham being one of the first universities in this country to adopt this course.

The outbreak of the second world war produced almost a revolution in Parsons' professional activities, and to a man of lesser merit and ability might have had most unfortunate consequences. At this time he was Professor of Children's Diseases, Subdean of the Medical Faculty, a Councillor of the Royal College of Physicians, London, and busily engaged in practice, teaching, and research. He accepted, in addition to all these responsibilities, the onerous task of Medical Officer for the Midland Region and here his exceptional ability was directed into administration in most difficult and trying times. These served as fresh fields for his fertile and imaginative mind, and under his wise, astute guidance the organization ran smoothly and efficiently and was able to deal with large numbers of wounded service men and air-raid casualties. His advice was frequently sought by the medical staffs of the hospitals, the medical services of the Army, the Air Force, and the Ministry of Health. His tact and capacity for unremitting hard work, 
earned him the respect and gratitude of all concerned. He did not, however, permit these administrative responsibilities to divorce him from active clinical work, but continued to maintain an energetic interest in child welfare. In 1942, he was awarded the Moxon Medal of the Royal College of Physicians, given ' to the person who is deemed to have most distinguished himself by observation and research in clinical medicine,' and the following year he delivered before the College the Charles West Lecture on the 'Prevention of Neonatal Disease and Neonatal Death'.

Before the end of the war Parsons was appointed Dean of the Faculty of Medicine in Birmingham, when the problems and difficulties of undergraduate instruction were formidable due to overcrowding and depleted staffs. The fact that the standard was not only maintained but the number of students increased was due in no small measure to his administrative skill. The war over, the return of the various departments to a peace-time footing and their desires for improvement and expansion, as well as the establishment of full-time University clinical departments, demanded a steadily increasing amount of his time and thought. He carried the burden of these responsibilities with equanimity, and the smooth and satisfactory manner whereby many of the schemes came to fruition gave still further evidence of his genius for administration.

Reference must also be made to the part he played in the promotion of the Birmingham Institute of Child Health. In 1930, at his instigation, discussions were inaugurated between the University and Birmingham City Council to formulate a plan to fuse and integrate the preventive and curative aspects of child health. Initially progress was slow and negotiations were also held up by the war, and it was not until 1945 that his plan was finally approved by Birmingham City Council, the University, and the Children's Hospital. This Institute, whose Council is composed of representatives appointed by these three bodies, fulfilled Parsons' ambitions, and the scheme he had evolved was the first complete one in this country. He remained an active and much valued member of the Council up to the time of his death.

Parsons' pre-eminent services to his country received national recognition in 1946 when he was knighted. During the last few years he had been the recipient of many further honours and awards. In 1947 he was elected a Fellow of the Royal
College of Obstetricians and Gynaecologists and in 1948 a Fellow of the Faculty of Radiologists. The award he valued highest, not so much for himself but for Birmingham University and the medical profession, was his election to the Fellowship of the Royal Society two years ago. He was Harveian Orator to the Royal College of Physicians for 1950, and a few days before his death he delivered the Harben Lectures to the Royal Institute of Public Health and Hygiene.

This sketchy and incomplete representation of some aspects of Sir Leonard Parsons' professional career, attainments and honours, fails to give any real indication of his character, individuality, and great gifts. He had a gentleness, a kindness, and a tolerance that remained unblemished and was never altered by the many awards and recognitions of his eminence. He remained a simple and a humble man, in some ways shy and retiring, and he never sought publicity. He never allowed himself to be ruffied or hurried, but remained calm and imperturbable whatever the circumstances might be. His high moral character, his earnestness of purpose, and his scrupulous honesty and open-mindedness endeared him to all and won many to his side. At the same time Parsons had vision and imagination, but his opinions were always practical although fundamental principles were uppermost in his mind. He had determination to accept nothing but the best, and having so made up his mind he would strive to achieve the objective and could be a forcible and powerful opponent to compromise. His mind was clear, quick, and lucid; he had a very retentive memory and his powers of sustained concentration were nothing short of remarkable. He had flexibility of intelligence, vigour, and energy which were intrinsic features of his genius. He was a deeply and earnestly religious man, and would never stoop to any action that might even appear to be mean, underhand, or unjust.

Sir Leonard Parsons was spared ill-health, pain or suffering. He died swiftly and unexpectedly on a Sunday morning (December 17, 1950) after his customary attendance at church, in his own home and surrounded by his family.

Paediatricians the world over will mourn the passing of a truly great and noble man; few, if any, have done as much as he to promote the welfare of infants and children during the last half century.

J.M.S. 